\title{
SUPPLY CHAIN MANAGEMENT IN A PRODUCTION COMPANY
}

\author{
Katarzyna Grotkiewicz*, Agnieszka Peszek, Przemysław Obajtek \\ Department of Production Engineering, Logistics and Applied Computer Science, University of \\ Agriculture in Krakow, Krakow, Poland
}

Katarzyna Grotkiewicz ORCID 0000-0001-8564-0928; Agnieszka Peszek ORCID 0000-0002-6801-8229;

*Corresponding author: e-mail: k.grotkiewicz@urk.edu.krakow.pl

\begin{tabular}{|c|c|}
\hline ARTICLE INFO & ABSTRACT \\
\hline $\begin{array}{l}\text { Article history: } \\
\text { Received: August } 2019 \\
\text { Received in the revised form: } \\
\text { September } 2019 \\
\text { Accepted: September } 2019 \\
\end{array}$ & $\begin{array}{l}\text { The purpose of the supply chain management is to ensure a competitive } \\
\text { advantage as well as specific added value for the benefit of all supply } \\
\text { chain links. Appropriate management practices generate many benefits, } \\
\text { allow for savings in particular segments of the supply chain by means } \\
\text { of cost reduction, which in turn directly leads to the competitiveness of }\end{array}$ \\
\hline $\begin{array}{l}\text { Key words: } \\
\text { supply chain, } \\
\text { management, } \\
\text { cross-docking, } \\
\text { company, } \\
\text { costs }\end{array}$ & $\begin{array}{l}\text { enterprises belonging to a specific chain. The above-mentioned issues } \\
\text { have become the subject of this thesis. Therefore, the British American } \\
\text { Tobacco distribution network is strategically analyzed. A location and } \\
\text { number of distribution centers will be i.a. taken into account. Reduction } \\
\text { in the number of distribution centers will be suggested in order to re- } \\
\text { duce logistics costs in the supply chain, i.e. transport and storage. The } \\
\text { studies were carried out based on the analysis of flows and route plan- } \\
\text { ning of the logistics operator for the transport of the company's prod- } \\
\text { ucts. }\end{array}$ \\
\hline
\end{tabular}

\section{Introduction}

Due to the dynamic development of production and trade, many companies, those operating globally in particular, are forced to constantly invest in their development and optimization. This is caused by demanding competition, the introduction of products having shorter life cycle and growing customer requirements (Michałek et al., 2010). The above-mentioned factors, together with the continuous progress of areas such as communication and transport, are the drivers of the development of supply chains and techniques of its effective management in enterprises focused on the total profit maximization.

The supply chain is a logistics concept that means the flow of raw materials, materials, semi-finished products, goods, as well as information and knowledge, from the place of their creation to final recipients, i.e. to customers (Rutkowski and Polak, 2016; Sadiku et al., 2018).

The efficiency and effectiveness of supply chain management is conditioned by the integration of all logistics processes in the supply chain. Supply chain management integrates appropriate functions, processes and actions that are responsible for various aspects of the flow of goods, information and money and thus contributes to effective brand building (Wincewicz-Bosy, 2013). 
Contemporary supply chain management is mainly focused on meeting customer requirements. One of the conditions for efficient and effective functioning of the supply chain is the decision-making process related to synchronization of physical, information and financial streams of demand and supply between participants in order to achieve their competitive advantage and added value for the benefit of all its links, customers and other entities (Barcik and Kubański, 2011).

According to many authors, processes and activities related to supply chain management, i.e. joint planning, forecasting, replenishment as well as inspection and control of related processes in the supply chain are possible due to the minimization of the total costs of product flows and information maintaining at the same time the level of supply quality required by the customer as well as ensuring the shortest possible order processing and the highest possible reliability, frequency and flexibility of supplies (Waściński, 2014; Ocicka, 2016, Agrawal and Narain, 2018; Kuboń and Krasnodębski, 2010; Thaku and Anbanandam, 2016).

\section{Material and Methods}

The main focus of the thesis concerns the role of supply chain management in modern business on the basis of an analysis of the strategic distribution network of British American Tobacco, which is part of the international tobacco group, British American Tobacco (BAT). Considerations will particularly regard the selected components of the chain along with the calculation of costs of the suggested logistics solutions with regard to the analyzed enterprise.

The studies were carried out based on the analysis of flows and route planning of the logistics operator for the transport of the company's products.

The purpose of this detailed analysis was to verify planned routes and adapt new ones, if there were changes to the network. For the purpose of the study's objective, the distribution network will be first analyzed with regard to the location and number of distribution centers. For the purposes of the analysis, indicative maps with cross-docks assigned to distribution centers will also be presented.

To determine possible savings, a scenario assuming a reduction in the number of distribution centers and resulting changes in transport will be specified. Due to the calculated costs for individual scenarios based on the detailed analysis of and route planning based on the introduced changes to the distribution network, possible savings for the annual budget estimation will be demonstrated together with the suggested changes in the supply chain.

British American Tabacco data from 20 January 2018 to 20 February 2018 was used for analysis. Ortec software was used to optimize logistics resources for the company. The purpose of the work was established by the need to select distribution network optimal for the company, which is one of the strategic decision-making problems of the logistics of the analyzed company, particularly due to the length of the distribution network and the large number of intermediate partners in the distribution network that extends delivery time of the final product to the customer. 
Supply chain management...

\section{Results and Discussion}

Activity of British-American Tabacco in Poland is a part of the international tobacco concern, British American Tobacco (BAT). The sales are in more than 200 markets worldwide. The British American Tobacco Group has two companies in the Polish market, seated in Augustów and Warsaw (http://www.bat.com.pl/).

Five distribution centers specified as a DC (Distribution Center) constitute the basis for BAT distribution in Poland. Each center handles assigned cross-dock warehouses and wholesale delivery points. These are: DC Dąbrowa Górnicza with a volume share of $30 \%$, DC Poznań $-35 \%$, plant DC Augustów - 7\%, and DC Teresin - $16 \%$ and DC Torun - approx. $12 \%$. The planning region is an area handled by the distribution center.

The costs of maintaining goods in the supply chain as well as the awareness that customers require goods to be delivered at the corresponding frequency and on time, confirm that organization of the supply chain so that to enable the quickest possible reaction to changes in market expectations, is of great importance. To meet the above requirements, BAT uses a cross-docking solution. Cross-docking includes unloading, segregation or goods consolidation and loading. This solution is used in the company mainly due to the fact that a product in the form of a finished product is taken out from one central location only, i.e. the plant in Augustów, from where it goes to individual distribution centers and cross-docks assortment management system adapted to the current needs of the client (Galbreth et al., 2008).

Figure 1 illustrates the map of Poland with distribution centers and the direction of goods flow from the factory to distribution centers and from centers to cross-docks in particular cities.
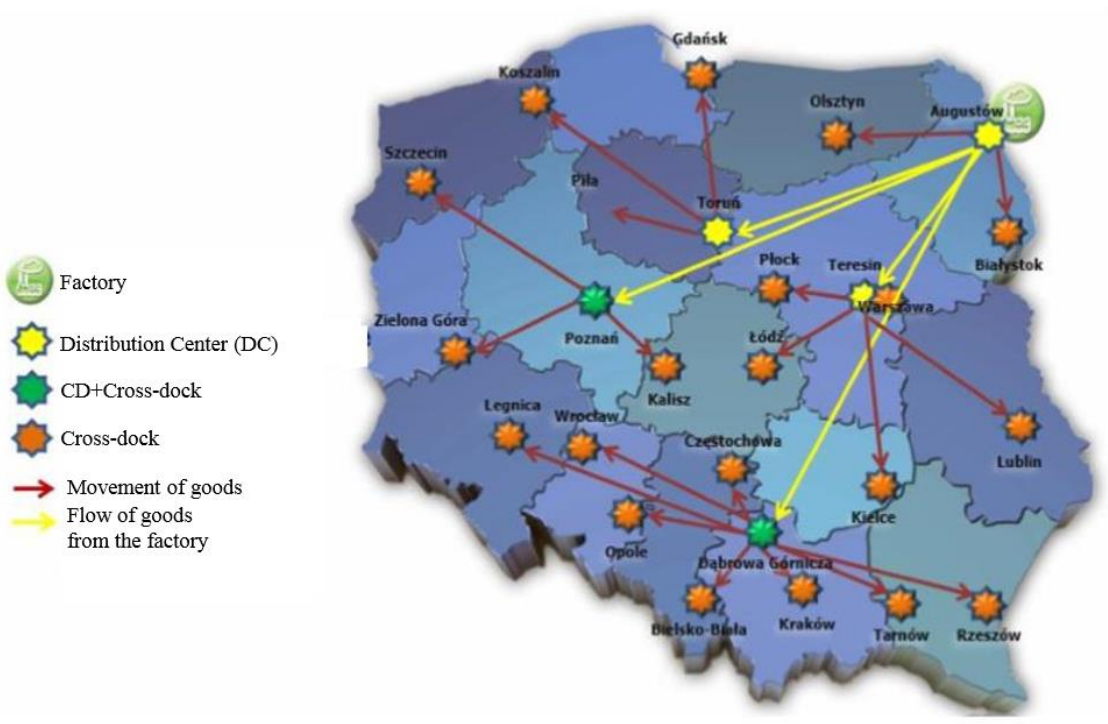

Figure 1. BAT Logistics structure in Poland 
Distribution constitutes one of the key links in the enterprise's logistics system. Product delivery from the supplier's warehouses to the customer's facilities is one of the major tasks. This process should be carried out at the lowest possible cost and should meet customer's requirements regarding service and support. In practice, this often means distribution cost reduction and customer service quality increase.

To follow the purpose of this article, due to the observation of the distribution network of British American Tobacco, it was possible to make a strategic decision to exclude DC Toruń from the distribution network and to try to generate savings in supply chain management by reduction in the company's logistics costs. The decision to turn off the distribution center in Toruń was based on such factors: DC Torun has the smallest transport fleet, it is located near two other operational centers (including modern DC Poznań), which leads to the consideration of DC transformation into a cross-dock and the sum of kilometers of deliveries to be made for DC in Torun is the second smallest value (Table 1) after DC in Augustów.

Based on the analyzes carried out, it may be stated that location of the plant in Augustów is the main factor affecting the number and location of distribution centers. Due to the poor development of road infrastructure, there are no motorways or highways that lead directly to the plant. What is more, with regard to the volume (number of high-volume points), the regions with the highest sales are located far from Augustów, which directly results in the number of distribution centers maintained (Fig. 2 and 3). High-volume points for BAT mean both short- and long-term customers which, in their customer profile built by the company, are characterized by high sales.

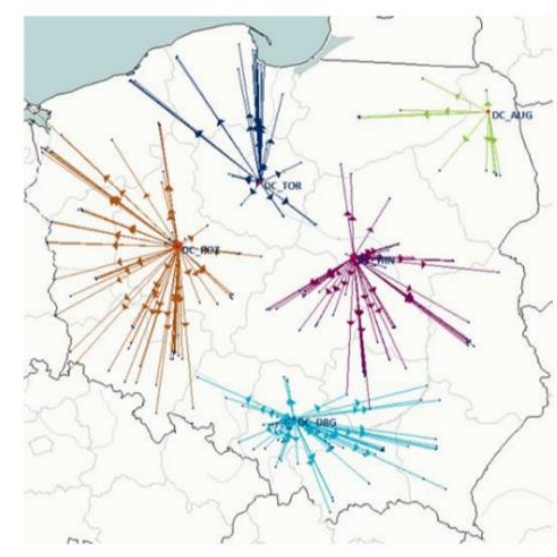

Figure 2. Cross-docks assigned to distribution centers

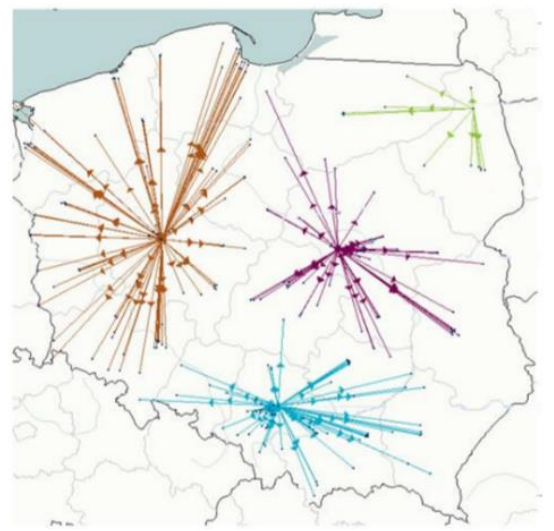

Figure 3. Optimal cross-dock assignment to distribution centers upon exclusion of DC in Toruń 
Supply chain management...

Before carrying out the detailed research regarding the logistics costs incurred, Tables 1 and 2 illustrate the sum of kilometers to be made during a week from DC in Torun and after its liquidation (transformation into a cross-dock).

DC in Torun has to made over two and a half thousand kilometers a week in total. Upon liquidation, some kilometers would be taken over by DC Augustów, DC Poznań and DC Teresin. As it results from Tables 1 and 2, the number of kilometers of routes made by DC Teresin will change slightly (approx. $200 \mathrm{~km}$ less). It is caused by automatic conversion of routes by the program based on the most optimal solution. In general, upon exclusion of DC Torun, the number of kilometers to be made per week will increase by approx. 2,000 km (precisely, $1,895.5 \mathrm{~km}$ ).

Moving to the next stage of the study regarding cost analysis, the costs of storage and transport were only taken into account in the calculations, assuming the lack of new potential wholesale customers; the costs of contract termination with the tenant of the facility constituting the distribution center were not taken into account as well. The analysis also does not include verification of risk associated with moving the warehouse process from the distribution center in Torun. Calculations for the detailed budget were made on the basis of route planning, where the planning period is one week, and on the basis of BAT data concerning storage costs. The below specified values are estimates of the annual budget. Both scenarios (scenario including DC in Toruń and scenario excluding DC in Toruń) were calculated assuming the same initial conditions (e.g. fixed price per liter of diesel fuel).

Table 1.

Sum of planned kilometers to be made per week

\begin{tabular}{|c|c|c|c|c|c|c|c|c|}
\hline \multirow[b]{2}{*}{$\begin{array}{l}\text { Distribution center } \\
\text { (DC) }\end{array}$} & \multirow[b]{2}{*}{ Vehicle } & \multicolumn{7}{|c|}{ Day } \\
\hline & & Vehicle No. & Mon & Tue & Wed & Thu & Fri & $\mathrm{Km}$ in total \\
\hline \multirow{3}{*}{ DC Augustów } & 1 & DSSAUG & 204.3 & 0.0 & 0.0 & 0.0 & 0.0 & \multirow{3}{*}{1021.5} \\
\hline & 2 & DSSAUG3 & 0.0 & 0.0 & 204.3 & 0.0 & 204.3 & \\
\hline & 3 & DSSAUG3b & 0.0 & 204.3 & 0.0 & 204.3 & 0 & \\
\hline \multirow{3}{*}{$\begin{array}{l}\text { DC Dąbrowa } \\
\text { Górnicza }\end{array}$} & 1 & DSSBDG & 0 & 485.1 & 485.1 & 485.1 & 485.1 & \multirow{3}{*}{3835.2} \\
\hline & 2 & DSSBDG3 & 378.7 & 136.8 & 378.7 & 136.8 & 378.7 & \\
\hline & 3 & DSSBDG3b & 485.1 & 0.00 & 0.00 & 0.00 & 0.00 & \\
\hline \multirow{4}{*}{ DC Poznań } & 1 & DSSPOZ & 422.8 & 521.4 & 209.9 & 521.4 & 209.9 & \multirow{4}{*}{7218.3} \\
\hline & 2 & DSSPOZ3 & 669.2 & 632.1 & 669.2 & 632.1 & 669.2 & \\
\hline & 3 & DSSPOZ33 & 547.1 & 0.0 & 547.1 & 0.0 & 547.1 & \\
\hline & 4 & DSSPOZc & 0.0 & 209.9 & 0.0 & 209.9 & 0.0 & \\
\hline DC Toruń & 1 & DSSTOR3 & 508.0 & 507.4 & 507.4 & 507.4 & 507.4 & 2537.6 \\
\hline \multirow{5}{*}{ DC Teresin } & 1 & DSSTRN & 0.0 & 0.0 & 434.6 & 0.0 & 434.6 & \multirow{5}{*}{3437.3} \\
\hline & 2 & DSSTRN3 & 0.0 & 279.8 & 0.0 & 279.8 & 0.0 & \\
\hline & 3 & DSSTRN3b & 611.8 & 0.0 & 0.0 & 0.0 & 0.0 & \\
\hline & 4 & DSSTRN3sd & 180.2 & 0.0 & 448.0 & 0.0 & 448.0 & \\
\hline & 5 & DSSTRN4 & 64.1 & 64.1 & 64.1 & 64.1 & 64.1 & \\
\hline
\end{tabular}


K. Grotkiewicz, A. Peszek, P. Obajtek

Table 2

Sum of planned kilometers to be made per week upon exclusion of DC in Toruń

\begin{tabular}{|c|c|c|c|c|c|c|c|c|}
\hline & & & & & Day & & & \\
\hline $\begin{array}{l}\text { Distribution center } \\
\text { (DC) }\end{array}$ & Vehicle & Vehicle No. & Mon & Tue & Wed & Thu & Fri & $\begin{array}{c}\mathrm{Km} \text { in } \\
\text { total }\end{array}$ \\
\hline \multirow{3}{*}{ DC Augustów } & 1 & DSSAUG & 0.0 & 524.1 & 0.0 & 524.1 & 0.0 & \multirow{3}{*}{3034.2} \\
\hline & 2 & DSSAUG3 & 733.5 & 0.0 & 524.1 & 0.0 & 524.1 & \\
\hline & 3 & DSSAUG3b & 204.3 & 0.0 & 0.0 & 0.0 & 0.0 & \\
\hline \multirow{3}{*}{$\begin{array}{l}\text { DC Dąbrowa } \\
\text { Górnicza }\end{array}$} & 1 & DSSBDG & 485.1 & 485.1 & 485.1 & 485.1 & 485.1 & \multirow{3}{*}{3835.2} \\
\hline & 2 & DSSBDG3 & 0.0 & 136.8 & 0.0 & 136.8 & 0.0 & \\
\hline & 3 & DSSBDG3b & 378.7 & 0.00 & 378.70 & 0.00 & 378.70 & \\
\hline \multirow{5}{*}{ DC Poznań } & 1 & DSSPOZ & 217.5 & 521.4 & 209.9 & 521.4 & 209.9 & \multirow{5}{*}{9820.2} \\
\hline & 2 & DSSPOZ3 & 669.2 & 632.1 & 669.2 & 632.1 & 669.2 & \\
\hline & 3 & DSSPOZ33 & 423.3 & 595.9 & 595.9 & 595.9 & 595.9 & \\
\hline & 4 & DSSPO3b & 547.1 & 0.0 & 0.0 & 0.0 & 0.0 & \\
\hline & 5 & DSSPOZc & 0.0 & 209.9 & 547.1 & 209.9 & 547.4 & \\
\hline \multirow{5}{*}{ DC Teresin } & 1 & DSSTRN & 180.2 & 0.0 & 0.0 & 0.0 & 0.0 & \multirow{5}{*}{3256.1} \\
\hline & 2 & DSSTRN3 & 0.0 & 279.8 & 0.0 & 279.8 & 0.0 & \\
\hline & 3 & DSSTRN3b & 611.8 & 0.0 & 611.8 & 0.0 & 611.8 & \\
\hline & 4 & DSSTRN3sd & 0.0 & 0.0 & 180.2 & 0.0 & 180.2 & \\
\hline & 5 & DSSTRN4 & 64.1 & 64.1 & 64.1 & 64.1 & 64.1 & \\
\hline
\end{tabular}

Using the Ortec Route Scheduling program, Table 3 and 4 present the results of the conversion of i.a. transport costs, number of hours, number of pallets, loading volumes etc. for transport planning for the variant with and without DC Torun. Upon the exclusion of DC Torun, an increase in the number of kilometers on the planned routes and thus the working time of drivers may be observed. What is more, this action lead to the increase in the percentage of car loading, which directly results in more efficient use (in table 3 and 4: number of colli to deliver which means number of items to be shipped).

Table 5 presents the budgets for the scenario with the number of distribution centers left unchanged and the scenario assuming the exclusion of the distribution center in Torun. Upon the center transformation into a cross-dock, it is estimated that there will be a decrease in storage costs by approx. $3 \%$ and a simultaneous increase in transport costs of $3 \%$ per year. However, due to significantly higher storage costs compared to transport costs, an estimate of an annual sum of costs will result in savings of approx. 3.5\% (approx. PLN 600,000). As it was mentioned before, the analysis did not take into account the costs of DC Torun transformation into a cross-dock or the costs of lease contract termination for warehouse space in DC Torun. Calculated savings, however, allow for practical, initial analysis of the further development of British American Tobacco. The DC Torun liquidation scenario may be considered e.g. upon the termination of the current warehouse space lease contract, which allows to avoid the costs of contract termination and gives the time needed to plan changes in the supply chain for the entire enterprise. 
Supply chain management...

Table 3.

Results of transport planning for the variant with DC in Torun

\begin{tabular}{lccc}
\hline & RESULTING SCHEDULE & \\
\hline & Monday & Tuesday, Thursday & Wednesday, Friday \\
\hline Total costs of schedule & 0 & 0 & 0 \\
Total calculation costs & 5928 & 4453 & 5615 \\
Km schedule & 4222,1 & 3041 & 3948,8 \\
Total number of working hours & $70: 30$ & $51: 10$ & $66: 30$ \\
Total overtime hours & $0: 00$ & $0: 00$ & $0: 00$ \\
Total driving time of vehicles & $60: 30$ & $43: 10$ & $57: 00$ \\
Number of vehicles & 19 & 19 & 19 \\
Number of orders & 22 & 22 & 22 \\
Planned vehicles & 10 & 9 & 10 \\
Planned trips & 10 & 9 & 10 \\
Planned orders & 20 & 16 & 19 \\
Total quantity of kg deliver & 0 & 0 & 0 \\
Total quantity of kg pick up & 0 & 0 & 0 \\
Total number of pallets to deliver & 5055 & 4451 & 4900 \\
Total number of pallets to pick up & 0 & 0 & 0 \\
Total number of colli to deliver & 5055 & 4451 & 4900 \\
Total quantity of colli to pick up & 0 & 0 & 0 \\
\hline & & Source: Data generated by Ortec Route Scheduling
\end{tabular}

Table 4.

Results of transport planning for the variant without DC in Torun

\begin{tabular}{lccc}
\hline \multicolumn{4}{c}{ RESULTING SCHEDULE } \\
\hline & Monday & Tuesday, Thursday & Wednesday, Friday \\
\hline Total costs of schedule & 0 & 0 & 0 \\
Total calculation costs & 6379 & 4932 & 5992 \\
Km schedule & 4514,8 & 3449,3 & 4266,5 \\
Total number of working hours & $76: 15$ & $58: 12$ & $72: 21$ \\
Total overtime hours & $0: 00$ & $0: 00$ & $0: 00$ \\
Total driving time of vehicles & $65: 45$ & $49: 42$ & $62: 21$ \\
Number of vehicles & 19 & 19 & 19 \\
Number of orders & 22 & 22 & 22 \\
Planned vehicles & 11 & 9 & 10 \\
Planned trips & 11 & 9 & 10 \\
Planned orders & 21 & 17 & 20 \\
Total quantity of kg deliver & 0 & 0 & 0 \\
Total quantity of kg pick up & 0 & 0 & 0 \\
Total number of pallets to deliver & 5321 & 4717 & 5166 \\
Total number of pallets to pick up & 0 & 0 & 0 \\
Total number of colli to deliver & 5321 & 4717 & 5166 \\
Total quantity of colli to pick up & 0 & 0 & 0 \\
\hline
\end{tabular}


K. Grotkiewicz, A. Peszek, P. Obajtek

Table 5 .

Detailed budget for the variant with and without DC Torun'

\begin{tabular}{|c|c|c|c|c|c|c|}
\hline & \multicolumn{3}{|c|}{ Annual cost (PLN) } & \multicolumn{3}{|c|}{ Percent of total costs $(\%)$} \\
\hline & Transport & Storage & Total & Transport & Storage & $\begin{array}{c}\text { Varian } 1 \text { vs } \\
\text { variant } 2 \\
\end{array}$ \\
\hline $\begin{array}{l}\text { Variant } \\
\text { with DC } \\
\text { Toruń }\end{array}$ & $\begin{array}{c}6488 \\
524\end{array}$ & 10579845 & $\begin{array}{c}17068 \\
369\end{array}$ & 38 & 62 & \\
\hline $\begin{array}{l}\text { Variant } \\
\text { without } \\
\text { DC Toruń }\end{array}$ & $\begin{array}{c}6635 \\
111\end{array}$ & 9797447 & $\begin{array}{c}16474 \\
698\end{array}$ & 41 & 59 & -3.48 \\
\hline & & & -593671 & & & \\
\hline
\end{tabular}

\section{Conclusions}

On the basis of the set goal and study scope, the analyzes carried out using Ortec software for logistics resources optimization for British American Tobacco Polska summed up the analyzed distribution network for the variant with DC Torun and after DC transformation into a cross-dock. Annual transport cost and storage costs were only taken into account.

The following practical conclusions can be drawn on the basis of the analysis of the distribution network:

1. DC Torun has the smallest transport fleet, it is located near two other operational centers, which leads to the consideration of DC transformation into a cross-dock.

2. Upon DC Torun liquidation, the number of routes it made will be taken over by DC Augustów and DC Poznań in particular. Therefore, the number of kilometers to be made per week will increase by approx. 2,000, which results in an increase of $10.5 \%$ per week.

3. Upon exclusion of DC Torun, the number of route kilometers and the drivers' working time will be increased, however the percentage of car loading will also increase, which directly leads to more efficient use of the transport fleet.

4. Due to the use of cross-docking in BAT, transport activities may be reduced and it may significantly affect the rate of responses to customer needs while maintaining high delivery standards.

5. Due to the transformation of DC in Torun into a cross-dock, annual transport costs will increase at a simultaneous decrease in storage costs. However, due to higher storage costs in relation to transport costs, this allows for savings of approx. PLN 600,000 per year.

\section{References}

Agrawal, P., Narain, R. (2018). Digital supply chain management: An Overview. IOP Conference Series Materials Science and Engineering, 455(1). DOI: 10.1088/1757-899X/455/1/012074

Barcik, R., Kubański, M. (2011). Współczesne trendy w zarządzaniu łańcuchem dostaw. Logistyka, 2, 55-66.

British-American Tabacco (2019). Available on: http://www.bat.com.pl/ (accessed, 2019). 
Supply chain management...

Galbreth, M.R., Hill, J.A., Handley, S. (2008). An Investigation of the Value of Cross-Docking for Supply Chain Management. Journal of Business Logistics, 29, 225-239. DOI: 10.1002/j.21581592.2008.tb00076.x

Kuboń, M., Krasnodębski, A. (2010). Logistic costs in competitive strategies of enterprises. Agricultural Economics, 56(8), 397-402.

Sadiku M.N.O., Eze, K.G., Musa, S.M. (2018). Supply Chain Management. International Journal of Engineering Research, 7(8), 137-139.

Michałek, R., Grotkiewicz, K., Kuboń, M., Sporysz, M. (2010). Methodical aspects of determination of scientific and technical progress in macro- and microeconomic tests. Agricultural Engineering, $14,197-205$

Ocicka, B. (2016). Współczesne strategie zarządzania międzynarodowymi łańcuchami dostaw. Zeszyty Naukowe Uniwersytetu Ekonomicznego w Katowicach, 283, 61-74.

Rutkowski, K., Polak, P. (2016). Zarządzanie łańcuchem dostaw w XXI wieku. Oficyna Wydawnicza SGH - Szkoła Glówna Handlowa, 5-8, 152-157.

Thaku, V., Anbanandam, R. (2016). Shift from product supply chain management to services supply chain management: a review. International Journal of Services and Operations Management 23(3), 316-346. DOI: 10.1504/IJSOM.2016.074817

Waściński, T. (2014). Procesy logistyczne w zarządzaniu łańcuchem dostaw. Zeszyty Naukowe, 103, 25-38.

Wincewicz-Bosy, M. (2013). Miejsce logistyki i łańcucha dostaw w zarządzaniu przedsiębiorstwem. Zeszyty Naukowe Wyższej Szkoty Bankowej we Wrocławiu, 1(33), 177-192.

\section{ZARZADZANIE LAŃCUCHEM DOSTAW W PRZEDSIĘBIORSTWIE PRODUKCYJNYM}

Streszczenie. Celem pracy jest przeprowadzenie analizy strategicznej sieci dystrybucyjnej firmy British American Tobacco. Pod uwagę brana będzie lokalizacja oraz liczba centrów dystrybucyjnych. Zaproponowana zostanie redukcja ilości centrów dystrybucyjnych w celu zmniejszenia kosztów logistycznych $w$ łańcuchu dostaw tj. transportu oraz magazynowania. Badania przeprowadzono w oparciu o analizę przepływów i planowania tras realizowanych przez operatora logistycznego dla przewozu produktów firmy.

Słowa kluczowe: łańcuch dostaw, zarządzanie, cross-docking, przedsiębiorstwo, koszty 